\title{
Analysis of Granting Financial Independence to Local Government in line With Their Constitutional Duties/Functions.
}

\author{
Adisa, Olufemi Peniel \\ Department Of Political Science \\ School of Arts and Social Sciences \\ Emmanuel Alayande College of Education Oyo, Oyo State \\ E-mail: Penielizabeth824@gmail.com; dnpenieliza@eacoed.edu.ng \\ $\&$ \\ Ogunbunmi, Solomon Tunde \\ Department Of Economics \\ School of Arts and Social Sciences \\ Emmanuel Alayande College of Education Oyo, Oyo State \\ E-mail: Ogunbumist@yahoo.com
}

Received: Aug. 20, 2019 Accepted: Sep. 12, 2019 Online published: Nov. 30, 2019

doi:10.5296/ijhrs.v9i4.15304

URL: https://doi.org/10.5296/ijhrs.v9i4.15304

\begin{abstract}
The paper considers the granting of financial independence (autonomy) to Local government against their constitutional against their constitutional duties. In doing this, the researcher considered the origin of local, meaning, types, functions, sources of revenue, problems of Local government and way out. Researcher used questionnaire as the instrument of data generation while paired simple t- statistics of data analysis was used for the collected data. Finally, recommendations were made on the need for financial independence of the local government and ways of preventing its abuse.
\end{abstract}

Keywords: financial independence, governance, dispersal of governance, leadership 


\section{Introduction}

Local government as a third tier of administration in Nigeria, has its origin ever since the days of colonial administration. This was done for the administrative conveniences, because it was seen as a means of bringing government nearer to the people at the grass-root. After granting independence to the country, as means of dispersal of governance, National Assembly legislated laws establishing the existence or the creation of local government in Nigeria by the state government subject to the approval of National Assembly and of which we have 774 constitutionally recognised local governments in Nigeria today.

Local government in Nigeria has passed through many reforms ranging from Native authority, chief-in-council, and finally to chief-and-council. The 1976 federal and state government collaboration on extensive reforms was basically to achieve the following objectives:

$\checkmark$ To make appropriate services and development activities responsive to local wishes and initiatives by devolving or delegation them to local representatives.

$\checkmark$ To facilitate the exercise of democratic (self) government close to the grassroots of our society and to encourage initiative and leadership potential,

$\checkmark$ Mobilisation of human material resources through the involvement of members of the public in their local development,

$\checkmark$ To provide a two way channel of communication between local communities and government (both State and Federal).

Furthermore, Local Governments can distinguished in two ways,

1. On the basis of the number of Local Governments in a particular locality, this is divided into two,

i. Single tier Multi-purpose

ii. Multi-tier Local Governments

2. On the basis of their structure, and these are:

i. Councils or councillor type

ii. Mayorial type

iii. City manager type

\section{Developmental stages of Local Governments in Nigeria}

Local Governments in Nigeria passed through some developmental stages before getting to its present status, and these in the submission of official Gazette (Nigeria, Federal Republic 1976), are;

Native Authority

County Council System

District Council 


\section{MInstitute ${ }_{\text {Mnin }}^{\text {Macrothin }}$}

The Local Council

The Sole Administratorship System

The Council Manager System

The Development Administration

These clearly shows that, Local Governments as a third tier of administration in Nigeria are not a spontaneous entity with which those who brought it into existence does so for a purpose.

\section{Conceptual Clarification}

Several scholars has given various definitions and meanings to local government. Some of these will be briefly looked at.

One of the most acceptable definitions of LG to us is offered by Mawhood (1993: VII \& 2). It defines Local Governments as,

bodies ... separated by law ... (and have) local representatives (and) ... formal power to decide on a range of public matters .... Their right to make decisions is entrenched by the law and can only be altered by a new legislation. They have resources, which subject to the stated limits, are spent and invested at their discretion.

According to United Nations office in Public administration, Local Governments is defined as "a political subdivision of a nation or ( in a federal system) state, which is constituted by law and has a substantial control of local affairs including the powers to impose taxes or to exert labour for prescribe purposes. The governing body of such an entity is elected". And many others.

\section{Local Government Financial Autonomy}

Financial autonomy refers to ability to decide freely on its internal financial affairs. The ability to manage its funds independently enables an institution to set and realise its strategic aims. (2019 World book Encyclopedia)

Local government autonomy can be defined as "the freedom of the local government to recruit and manage its own staff, raise and manage its own finances, make by-laws and policies, and discharge its functions as provided by law without interference from the higher governments" (Ogunna 1996: 350). This includes political, financial and administrative autonomy. Financial autonomy of local government is the "freedom to impose local taxation, generate revenue within its assigned sources, allocate its financial and material resources, determine and authorize its annual budget without external interference. It must be noted that local government autonomy is not absolute; the third tier of government retains functional and fiscal relations with the higher tiers of government, however, the relationship must function within the relevant law.

Financial autonomy of local governments will enable them to carry out their responsibilities in the areas of health, education, rural infrastructure, agricultural development and social services to the people that brought them to power." (Nigeria, Federal Republic, 2001)

Financial autonomy of local government entails the "freedom to impose local taxation, 
generate revenue within its assigned sources, allocate its financial and material resources, determine and authorize its annual budgets without external interference", fiscal autonomy is therefore the bedrock and most important aspect ... (Nigeria, Federal Republic 2006)

\section{Usefulness/ Importance of Local Government}

Apart from the above mentioned functions placed on Local Governments, there are other indispensable and indisputable usefulness/ importance for the existence of Local Governments and some of these are;

i. The first and most important purpose of Local Government administration is to bring government nearer to the people

ii. A derivative purpose is to foster a sense of belonging from grassroot by ensuring the participation of citizens in deciding or deliberation on matters affecting them.

iii. It also encourage initiative and development of leadership potentials from the grassroot.

iv. As a third tier of government, it is a countervailing power to other governmental levels, and has a power sharing device, it helps to localize and confine problems that may arise (Babatope 2010)

Purposes and Functions of Local Government

Having known what local government and financial independence means in conjunction with local government financial independence alongside with its importance/usefulness, it is important here to discuss the purposes and functions to expected to be performing by Local Governments that led to it creation, before we can now decide if its financial independence is justified or not.

According Babatope, O.A. (2010), he opines that the fourth schedule to the 1999 constitution sets out the main functions of Local Government councils. In general, these functions can be classified into three broad are;

a) Those functions that are the exclusive responsibility of the Local Government councils;

b) Those functions in which they share responsibility with the state government; and

c) Those functions that may be assigned by the state government.

Under the category (a) above, Local Governments performs the following functions;

i. Registration of births, marriages and death;

ii. Provisions and maintenance of refuse disposal;

iii. Collection of rates, radio and television lincences;

iv. Licensing of bicycles, motorcycles, trucks, canoe, whell barrows and carts

v. Establishments, maintenance regulation of cemeteries, markets, motor packs, public conveniences and homes for the destitutes or infirm;

vi. Construction and maintenance of roads, streets, drains and other public highways;

vii. Assessments of privately owned houses or tenements; 
viii. Control and regulation of outdoor advertising and boarding, pets, shops, and kiosks, restaurants.

ix. Provisions and maintenance of slaughter's houses and slaughter's slab

$\mathrm{x}$. Naming of roads and buildings

In respect to those functions that are of shared responsibility with state government, Babatope (2010) opines further that, as spells out by the constitution, Local Governments in conjunction with state government can;

i. Provide and maintain primary schools;

ii. Develop and maintain agriculture and other natural resources ( except exploitation of mineral which is the exclusive responsibility of the Federal Government)

iii. Provide and maintain health care services.

iv. Town and country planning, building development control

v. Involvement in Agricultural extension

vi. Provide and maintain rural and semi-urban water supply

vii. Provide and maintain roads, street lights and drainages.

Looking at all the functions expected to be performed or being performed by the local government, it becomes an indisputable fact that financial requirements to meet all these functions are no doubt enormous. But for the confirmation of this reasons, questionnaires were distributed to elicit peoples response to know if truly local government needed to be granted financial independence or not.

\section{Hypothesis}

1. There is no significant relationship between local government financial independence and their effective performance/functions.

2. There is no significant relationship between local government financial independence and their accountability and transparency.

Table 1. Data Presentation

\begin{tabular}{|c|c|c|c|c|c|c|c|}
\hline $\mathrm{S} / \mathrm{N}$ & QUESTIONS & \multicolumn{2}{|c|}{ YES } & \multicolumn{2}{|c|}{$\mathrm{NO}$} & \multicolumn{2}{|c|}{ TOTAL } \\
\hline & & No & $\%$ & $\mathrm{No}$ & $\%$ & no & $\%$ \\
\hline 1 & $\begin{array}{l}\text { In line with the tenets of democracy, are you of the } \\
\text { opinion that local government be given financial } \\
\text { independence? }\end{array}$ & 101 & 91.8 & 09 & 8.2 & 110 & 100 \\
\hline 2 & $\begin{array}{l}\text { Do you agree that if local government is given financial } \\
\text { independence they will perform better? }\end{array}$ & 103 & 93.6 & 07 & 6.4 & 110 & 100 \\
\hline 3 & $\begin{array}{l}\text { Are you of the opinion that local government should not } \\
\text { be given financial independence because of corrupt } \\
\text { practices at the local level? }\end{array}$ & 20 & 18.2 & 90 & 81.8 & 110 & 100 \\
\hline 4 & $\begin{array}{l}\text { Do you agree that given financial independence to local } \\
\text { government can not necessarily increase corruption if all } \\
\text { financial mechanisms are implemented? }\end{array}$ & 102 & 92.7 & 08 & 7.3 & 110 & 100 \\
\hline 5 & $\begin{array}{l}\text { Do you subscribe to the notion that state should remain } \\
\text { intermediary between local and federal government in } \\
\text { the disbursement of their allocation? }\end{array}$ & 10 & 9.1 & 100 & 90.9 & 110 & 100 \\
\hline 6 & Can you rate the performance of local government to be & 87 & 70.1 & 23 & 20.9 & 110 & 100 \\
\hline
\end{tabular}




\section{Macrothink}

International Journal of Human Resource Studies

ISSN 2162-3058

2019, Vol. 9, No. 4

\begin{tabular}{|c|c|c|c|c|c|c|c|}
\hline & $\begin{array}{l}\text { better when their finances was not under the state } \\
\text { government? }\end{array}$ & & & & & & \\
\hline 7 & $\begin{array}{l}\text { Leadership training of the people is more common and } \\
\text { beneficial than that of state and federal government. }\end{array}$ & 81 & 73.6 & 29 & 26.4 & 110 & 100 \\
\hline 8 & $\begin{array}{l}\text { Functions of local government makes the people at the } \\
\text { local level have the impact of government. }\end{array}$ & 97 & 88.2 & 13 & 11.8 & 110 & 100 \\
\hline 9 & $\begin{array}{l}\text { Is it true that granting financial independence to } \\
\text { local government will make the administrators more } \\
\text { accountable to the electorates at local levels? }\end{array}$ & 104 & 94.5 & 06 & 5.5 & 110 & 100 \\
\hline 10 & $\begin{array}{l}\text { Granting financial independence to local government } \\
\text { makes will allow anti-graft agencies to know where and } \\
\text { who to probe directly and thereby promote financial } \\
\text { transparency. }\end{array}$ & 108 & 98.2 & 02 & 1.8 & 110 & 100 \\
\hline
\end{tabular}

\section{Data Analysis and Interpretation}

Table 2. On hypothesis 1: Which says; There is no significant relationship between local government financial independence and their effective performance/functions.

Questions

\begin{tabular}{l|l|l|l|l|l|l|l}
\hline S/N & \multicolumn{1}{|c|}{ QUESTIONS } & \multicolumn{2}{c|}{ YES } & \multicolumn{3}{c|}{ NO } & \multicolumn{2}{c}{ TOTAL } \\
\hline 1 & \multicolumn{1}{|c|}{$\begin{array}{l}\text { In line with the tenets of democracy, are you of the } \\
\text { opinion that local government be given financial } \\
\text { independence? }\end{array}$} & 101 & 91.8 & 09 & 8.2 & 110 & 100 \\
\hline 2 & $\begin{array}{l}\text { Do you agree that if local government is given financial } \\
\text { independence they will perform better? }\end{array}$ & 103 & 93.6 & 07 & 6.4 & 110 & 100 \\
\hline 6 & $\begin{array}{l}\text { Can you rate the performance of local government to be } \\
\text { better when their finances was not under the state } \\
\text { government? }\end{array}$ & 87 & 70.1 & 23 & 20.9 & 110 & 100 \\
\hline 7 & $\begin{array}{l}\text { Leadership training of the people is more common and } \\
\text { beneficial than that of state and federal government. }\end{array}$ & 81 & 73.6 & 29 & 26.4 & 110 & 100 \\
\hline 8 & $\begin{array}{l}\text { Functions of local government makes the people at the } \\
\text { local level have the impact of government. }\end{array}$ & 97 & 88.2 & 13 & 11.8 & 110 & 100 \\
\hline
\end{tabular}

Table 3. Paired Sample Statistics

\begin{tabular}{l|l|l|l|l|l|l|l}
\hline & Mean & $\mathrm{N}$ & $\begin{array}{l}\text { Std. } \\
\text { Deviation }\end{array}$ & $\begin{array}{l}\text { Std.Error } \\
\text { Mean }\end{array}$ & $\mathrm{T}$ & df & Sig (2-tailed) \\
\hline Pair YES & & 5 & 9.445 & 4.224 & & & \\
1 NO & 98.30 & 5 & 9.445 & 4.224 & 9.186 & 4 & .001 \\
& 16.20 & & & & & & \\
\hline
\end{tabular}

From the above analysis, it is clear that t-calculated is greater than t-table. The interpretation of which is that the hypothetical statement will be rejected. Which is to be restated that there is significant relationship between local government financial independence and their effective performancelfunctions. Meaning that if local government is given financial 


\section{Macrothink}

International Journal of Human Resource Studies

ISSN 2162-3058

2019, Vol. 9, No. 4

independence this will definitely improve and increase their effective performance/functions.

Table 4. On hypothesis 2: Which says; There is no significant relationship between local government financial independence and their accountability and transparency

\begin{tabular}{|c|c|c|c|c|c|c|c|}
\hline $\mathrm{S} / \mathrm{N}$ & QUESTIONS & \multicolumn{2}{|c|}{ YES } & \multicolumn{2}{|c|}{$\mathrm{NO}$} & \multicolumn{2}{|c|}{ TOTAL } \\
\hline & & No & $\%$ & No & $\%$ & no & $\%$ \\
\hline 3 & $\begin{array}{l}\text { Are you of the opinion that local government should not } \\
\text { be given financial independence because of corrupt } \\
\text { practices at the local level? }\end{array}$ & 20 & 18.2 & 90 & 81.8 & 110 & 100 \\
\hline 4 & $\begin{array}{l}\text { Do you agree that given financial independence to local } \\
\text { government can not necessarily increase corruption if all } \\
\text { financial mechanisms are implemented? }\end{array}$ & 102 & 92.7 & 08 & 7.3 & 110 & 100 \\
\hline 5 & $\begin{array}{l}\text { Do you subscribe to the notion that state should remain } \\
\text { intermediary between local and federal government in } \\
\text { the disbursement of their allocation? }\end{array}$ & 10 & 9.1 & 100 & 90.9 & 110 & 100 \\
\hline 9 & $\begin{array}{l}\text { Is it true that granting financial independence to } \\
\text { local government will make the administrators more } \\
\text { accountable to the electorates at local levels? }\end{array}$ & 104 & 94.5 & 06 & 5.5 & 110 & 100 \\
\hline 10 & $\begin{array}{l}\text { Granting financial independence to local government } \\
\text { makes will allow anti-graft agencies to know where and } \\
\text { who to probe directly and thereby promote financial } \\
\text { transparency. }\end{array}$ & 108 & 98.2 & 02 & 1.8 & 110 & 100 \\
\hline
\end{tabular}

Table 5. Paired Sample Statistics

\begin{tabular}{|l|l|l|l|l|l|l|l|}
\hline & Mean & $\mathrm{N}$ & $\begin{array}{l}\text { Std. } \\
\text { Deviation }\end{array}$ & Std.Error & $\mathrm{t}$ & $\mathrm{df}$ & Sig (2-tailed) \\
Mean & & & & \\
\hline Pair YES & & 5 & 49.287 & 22.042 & & & \\
1 & 68.80 & 5 & 49.287 & 22.042 & .626 & 4 & .565 \\
\hline & 41.20 & & & & & & \\
\hline
\end{tabular}

From the above analysis, it is clear that t-calculated is greater than t-table. The interpretation of which is that the hypothetical statement will be rejected. Which is to be restated that There is significant relationship between local government financial independence and their accountability and transparency.

Meaning that if local government is given financial independence this will definitely it will give more room for their accountability and transparency.

\section{Conclusion and Recommendation}

From all the submission above on the Consideration of granting financial independence to Local government against their constitutional duties, the research has clearly shown that 
granting financial independence to local government is a welcome idea by vast number of people that responded through the questionnaire distributed and attended to by the respondents, because, this was established that, doing so will give room for more effective performance by the tier of government, allow for transparency and accountability and will also entrench probity. Be that as it may, the following recommendations were offered by the researcher;

$>$ That National assembly should fastract in passing the bill proposing going back to financial independence of local governments as of the past and find a means of legalising it by amending the constitution to contain that so that state governors will have no choice of obeying it rather than buying off the states houses of Assembly for not approving granting of financial independence to their local governments.

$>$ In case of any violation of such law by any state, strict penalty should be attached to it, which can even include power of National Assembly to remove such governors.

$>$ That the National Assembly to legislate and legalise idea put forward by president Mohammadu Buhari that monthly allocation of all local government be sent to them directly without passing through the state governors.

$>$ The idea of retiring previous month allocation by these local government before qualifying for the next one should be legislated also as a means of checkmating financial misconducts.

$>$ Anti graft agencies are to be given free access into the financial activities of these local governments, so as to instil fear of being prosecuted in case of any financial recklessness.

$>$ Monthly publishing of financial transaction should be made compulsory, as a way of carrying the citizens/electorates along in order to promote political thrust and political participation.

$>$ Declaration of assets by the elected officials before or immediately on assumption of office and be done annually for cross checking in line with their official income.

\section{References}

Babatope, O. A. (2010). Introduction to Local and Urban Government Studies in Nigeria. Ibadan. Isegun Publishing Company.

Mawhood, P. C. (1993). Local Government in the Third World: Experience of Decentralization in Tropical Africa, South Africa: Africa Institute of South Africa.

Nigeria, Federal Republic. (1976). Guidelines for Local Government Reform, Kaduna: Government Printer.

Nigeria, Federal Republic. (1987). Report of the Political Bureau, Abuja; Directorate for Social Mobilization.

Nigeria, Federal Republic. (1999a). 1999 Constitution of the Federal Republic of Nigeria, 


\section{Macrothink}

International Journal of Human Resource Studies

ISSN 2162-3058 2019, Vol. 9, No. 4

Abuja: Federal Government Printer.

Nigeria, Federal Republic. (1999b). Annual Abstracts of Statistics 1999 Edition, Abuja: Federal Office of Statistics.

Nigeria, Federal Republic, (2001). Central Bank of Nigeria: Annual Report and Statement of Accounts for the Year Ended 31st December, 2001.

Nigeria, Federal Republic, (2003). Central Bank of Nigeria: Annual Report and Statement of Accounts for the Year Ended 31st December, 2003.

Nigeria, Federal Republic. (2006). Central Bank of Nigeria: Annual Report and Statement of Accounts for the Year Ended 31st December, 2006.

Nigeria, Federal Republic. (2007). Official Gazette, 94(24), 15 May, Lagos: Federal Government Printer

Ogunna, A. E. C. (1996). A Handbook on Local Government in Nigeria, Owerri: Versatile Publishers.

The world book encyclopedia. (Book, 2019) [WorldCat.org]

\section{Copyright Disclaimer}

Copyright for this article is retained by the author(s), with first publication rights granted to the journal.

This is an open-access article distributed under the terms and conditions of the Creative Commons Attribution license (http://creativecommons.org/licenses/by/4.0/). 